\title{
SurA, a periplasmic protein with peptidyl-prolyl isomerase activity, participates in the assembly of outer membrane porins
}

\author{
Pierre E. Rouvière ${ }^{1}$ and Carol A. Gross ${ }^{2}$ \\ Department of Stomatology, University of California, San Francisco, California 94143-0512 USA
}

\begin{abstract}
Little is known about either the process of periplasmic protein folding or how information concerning the folding state in this compartment is communicated. We present evidence that SurA, a periplasmic protein with peptidyl-prolyl isomerase activity, is involved in the maturation and assembly of LamB. LamB is a trimeric outer membrane porin for maltodextrins as well as the bacteriophage $\lambda$ receptor in Escherichia coli. We demonstrate that SurA is involved in the conversion of unfolded monomers into a newly identified intermediate in LamB assembly, which behaves as a folded monomer. The absence of SurA blocks the assembly pathway and leads to accumulation of species prior to the folded monomer. These species also accumulate when the stress sigma factor $\sigma^{\mathrm{E}}$ is induced by LamB overexpression. We suggest that accumulation of species prior to the generation of folded monomer is a stress signal sensed by $\sigma^{\mathrm{E}}$.
\end{abstract}

[Key Words: Peptidyl-prolyl isomerases; parvulins; outer-membrane proteins; extra-cytoplasmic stress; protein folding; SurA; LamB]

Received July 12, 1996; revised version accepted November 1, 1996.

Gram-negative bacteria have two cellular compartments: the cytoplasm and the periplasm, an extracytoplasmic compartment located between the cytoplasmic membrane and the outer membrane (OM) of the cell. Conditions in these two compartments are quite different. The cytoplasmic compartment is a very reducing, highly buffered, energy-rich environment. In contrast, the periplasmic compartment does not contain ATP (Wulfing and Pluckthun 1994) and is in continuity with the cell exterior through pores in the outer membrane. These pores allow small molecules and some specific substrates to exchange freely with the medium (Nikaido 1994). As a consequence, periplasmic conditions ( $\mathrm{pH}$, redox potential, and the presence of toxic molecules) fluctuate and reflect those of the external environment (Wulfing and Pluckthun 1994). The periplasmic compartment and the outer membrane thus constitute an interface of the cell with the environment by fulfilling the functions of barrier and of exchange. Optimal growth depends upon the ability of the cell to sense and respond to potentially deleterious changes in this compartment.

One general way cells sense stress is to monitor the buildup of protein-folding intermediates, a signal that

${ }^{1}$ Present address: Environmental Biotechnology Program, Central Research and Development, DuPont Company, Wilmington, Deleware 19880 USA.

${ }^{2}$ Corresponding author. can integrate the effects of a multiplicity of adverse external conditions including high temperature, extremes in $\mathrm{pH}$, solvents, or heavy metals. In cases where it has been studied, the chaperones and protein-folding catalysts are often part of the signal transduction cascade (McMillan et al. 1994). However, little is known about the agents facilitating the folding of periplasmic and OM proteins (OMPs) (Wulfing and Pluckthun 1994) or how information on the folding state in the periplasm is communicated. Most of the cytoplasmic chaperones involved in folding utilize ATP in their catalytic cycle (Craig 1993; Craig et al. 1993), making it unlikely that periplasmic homologs of these chaperones exist. Thus far, only the periplasmic disulfide bond reductases (Dsb proteins) have been shown to assist in general proteinfolding in the periplasm (Bardwell et al. 1991; Missiakas et al. 1994). The periplasmic Skp protein has also been suggested to affect outer membrane protein assembly (Chen and Henning 1996). It is likely that additional periplasmic proteins facilitating folding and preventing off-pathway reactions do exist. They are likely to be particularly important for porins, which must trimerize and insert in the outer membrane, a very slow process that requires on the order of $5 \mathrm{~min}$ for completion. By catalyzing the rapid conversion of the folding intermediates most sensitive to antifolding agents into more stable species, periplasmic chaperones would contribute to maintenance of the integrity of the OM under deleterious conditions. An appealing idea is that the cell may monitor 
the OMP assembly process to assess the level of periplasmic stress and maintain homeostasis of the periplasm.

The Escherichia coli alternative stress sigma factor, $\sigma^{\mathrm{E}}$, is involved in one of the few pathways known to respond to conditions in the periplasmic compartment of the cell. $\sigma^{E}$ is specifically activated by overproduction of OMPs and the activation signal is generated in the periplasm (Mecsas et al. 1993). Here, we have used the $\sigma^{\mathrm{E}}$ induction pathway to obtain information about the agents facilitating the folding of periplasmic and $O M$ proteins. We reasoned that restricting the assembly process at a step after the "signal" intermediate is generated should cause a buildup of this signal and induce $\sigma^{\mathrm{E}}$ activity. We therefore looked for recessive mutations that induced $\sigma^{E}$ activity. We obtained stable insertion mutations in the surA gene, previously identified because mutations in $\operatorname{sur} A$ result in a defect in stationary phase survival (Tormo et al. 1990). We show that the carboxyterminal portion of SurA is a novel peptidyl-prolyl isomerase (PPIase) that participates in a previously undetected step in OMP maturation: the generation of a folded monomer species. Unfolded monomer accumulates both in cells lacking SurA and in cells overexpressing OMPs, suggesting that accumulation of this species constitutes a signal for induction of $\sigma^{\mathrm{E}}$.

\section{Results \\ Disruption of surA increases $\sigma^{E}$ activity}

We performed insertion mutagenesis on a reporter strain carrying a $\sigma^{\mathrm{E}}$ promoter driving expression of the $\operatorname{lac} Z$ gene to identify recessive mutations that increased $\sigma^{\mathrm{E}}$ activity (see Materials and Methods). Whereas the parent colonies are light pink on McConkey lactose plates, high activity mutants would be expected to give dark red colonies. We obtained one stable mutant that gave small, dark red colonies. The insertion was mapped to $165 \mathrm{nu}^{-}$ cleotides downstream of the initiating codon of the sur $A$ gene at 1 min on the E. coli chromosome (see Materials and Methods). The insertion strain showed a 5- to 7-fold increase in $\sigma^{\mathrm{E}}$ activity at all three known $\sigma^{\mathrm{E}}$ promoters including rpoHP3 (Fig. 1A), rpoEP2 (Fig. 1B), and $\operatorname{deg} P$ (Fig. lC). This induction is comparable in magnitude to that obtained by massive overproduction of OMPs. A plasmid carrying only the surA gene (pPER93) was sufficient to restore wild-type phenotypes, indicating that the defect caused by insertion into surA did not result from polar effects on downstream genes.

\section{SurA is a PPIase}

Until recently, all known PPIases belonged to either the FKBP or the cyclophilin family of proteins. These families are defined by their sensitivity to the immunosuppressive drugs FK506 and Cyclosporin A, respectively. Members of each family share extensive sequence similarity among themselves although they may not interact with the immunosuppressive drug defining the family. There is no sequence homology between families. Re-
A
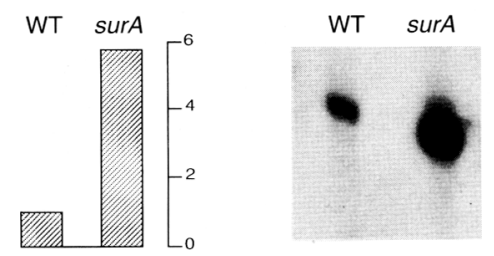

Figure 1. Activity of $\sigma^{\mathrm{E}}$ in the surA mutant. The activity of $\sigma^{\mathrm{E}}$ was measured from three $\sigma^{\mathrm{E}}$-dependent promoters in CAG16037 cells carrying the wild-type or the surA allele and growing exponentially in $\mathrm{M} 9$ complete glucose medium at $30^{\circ} \mathrm{C}$ $(A, B)$ or $\mathrm{M} 9$ labeling medium at $37^{\circ} \mathrm{C}(C)$. (A) $\beta$-galactosidase activity of the rpoHP3-lac $Z$ fusion normalized to the activity of the wild-type. Results are the average of four determinations with an error of $7 \%$. The activity of the wild-type was 120 Miller units. $(B)$ Transcription from the rpoEP2 promoter measured by S1 mapping as described (Rouvière et al. 1995). Quantitation of the transcripts by Phosphorlmager showed a sixfold increase in the surA mutant. (C) Immunoprecipitation of newly synthesized DegP and maltose binding protein (MBP). Cells were labeled with ${ }^{35} \mathrm{~S}$-TransMet (30-sec pulse, 30 -sec chase). TCA precipitated extracts were immunoprecipitated with antiMBP and anti-DegP antiserum. PhosphorImager quantitation of the DegP band showed a fourfold increase in the surA mutant. The synthesis of MBP is unaffected by the mutation in surA. A longer chase time showed no changes in the level of either DegP or MBP (data not shown).

cently, a new PPIase, called Parvulin, has been described in $E$. coli (Rahfeld et al. 1994). Because this protein does not share sequence similarity with either existing family, it is the founding member of a putative third family of PPIases (Rahfeld et al. 1994; Rudd et al. 1995). SurA contains two tandem domains (Rudd et al. 1995), each exhibiting similarity to the entire sequence of Parvulin.

To test whether SurA was a PPIase, we expressed a carboxy-terminally $\mathrm{His}_{6}$-tagged version of the protein from a plasmid. The tagged protein was functional in vivo because it reverted the phenotypes of the $\operatorname{sur} A$ insertion mutant. The carboxy-terminally tagged protein was purified from the periplasmic fraction. Amino-terminal analysis indicated the sequence Ala-Pro-GluVal-Val, as expected if SurA were cleaved after the signal sequence during secretion to the periplasm. The purified protein exhibited PPIase activity with a variety of artificial substrates (Table 1). This activity was not inhibited either by Cyclosporin A or FK506 (data not shown).

The activity of SurA was only $\sim 1 \%$ of that exhibited by amino-terminally His-tagged Parvulin itself under our assay conditions, raising the possibility that the low PPIase activity of our preparations was attributable to low levels of a contaminating PPIase with normal levels of activity, typically $\sim 10^{6} / \mathrm{M}$ per sec. To investigate this and also to determine whether a normal activity of the SurA could be masked by either the amino- or carboxyterminal regions of SurA, we further studied its PPIase activity by expressing its Parvulin domains alone, either separately or in tandem (see Fig. 2). Domain II, the two Parvulin domains in tandem, and intact SurA all had comparable low PPIase activity $\left(5 \times 10^{3}\right.$ to $6 \times 10^{3} / \mathrm{M}$ 
Table 1. Specificity of SurA for PPIase artificial substrates

\begin{tabular}{|c|c|c|c|c|c|c|}
\hline \multirow[b]{2}{*}{ Xaa } & \multicolumn{2}{|c|}{ SurA-His $_{6}$} & \multicolumn{2}{|c|}{$\mathrm{His}_{6}$-domain II } & \multirow{2}{*}{$\begin{array}{l}\text { Parvulin } \\
\text { relative activity } \\
(\%)\end{array}$} & \multirow{2}{*}{$\begin{array}{l}\text { RotA } \\
\text { relative activity } \\
|\%|\end{array}$} \\
\hline & $\begin{array}{c}k_{\mathrm{cat}} / K_{\mathrm{m}} \\
\left(\times 10^{3} / \mathrm{M} \text { per sec }\right)\end{array}$ & $\begin{array}{c}\text { relative activity } \\
(\%)\end{array}$ & $\begin{array}{c}k_{\mathrm{cat}} / K_{\mathrm{m}} \\
\left(\times 10^{3} / \mathrm{M} \text { per sec }\right)\end{array}$ & $\begin{array}{c}\text { relative activity } \\
|\%|\end{array}$ & & \\
\hline $\mathrm{Ala}$ & 6.4 & 100 & 6.1 & 100 & 100 & 100 \\
\hline Leu & 19.0 & 300 & 31.9 & 520 & 250 & 34 \\
\hline $\operatorname{Trp}$ & 3.7 & 60 & 5.4 & 88 & 73 & N.D. \\
\hline Phe & 5.4 & 85 & 4.4 & 72 & 160 & 29 \\
\hline $\mathrm{His}$ & 5.1 & 80 & 5.3 & 86 & 56 & 16 \\
\hline Lys & 3.2 & 50 & N.D. & N.D. & 50 & 5 \\
\hline Glu & 15.5 & 230 & 19.4 & 320 & 25 & 24 \\
\hline Gly & 1.1 & 20 & 0.8 & 13 & 0 & 27 \\
\hline
\end{tabular}

The specificity of the SurA-His ${ }_{6}$ and the His $_{6}$-derivative of the Parvulin-like domain II of SurA (His ${ }_{6}$-domain II) was tested for various Suc-Ala-Xaa-Pro-Phe-p-NA substrates. The SurA-His 6 used was purified by affinity chromatography on $\mathrm{Ni}^{2+}$ agarose from a periplasmic fraction. The $\mathrm{His}_{6}$-domain II used was purified from cytoplasmic extracts by affinity chromatography on $\mathrm{Ni}^{2+}$ agarose followed by chromatography on phenyl-Sepharose (Fig. 2B). The relative activities were normalized to the activity with the Ala substrate for each enzyme. For comparison, the relative activities of Parvulin and the periplasmic cyclophilin Rot $\mathrm{A}$, the most active extracellular PPIase and the most likely to contaminate periplasmic SurA-His 6 preparations, were presented. These values were calculated from the data of Rahfeld et al. (1994). The $k_{\mathrm{cat}} / K_{\mathrm{m}}$ for the Ala substrate of Parvulin was $6 \times 10^{6} / \mathrm{M}$ per sec.

per sec), whereas domain I had no detectable PPIase activity. We conclude that the PPIase activity of SurA is not masked and that SurA has low intrinsic PPIase activity with these short synthetic substrates. Several lines of evidence indicate that the PPIase activity we found came from SurA rather than from a contaminating PPIase. First, a mock purification from cells containing the vector alone gave no PPIase activity (data not shown). Second, intact SurA (purified from the periplasmic fraction), and the carboxy-terminal domain (domain II, purified from the cytoplasmic fraction) gave similar activities (Fig. 2A). Third, further purification of the $\mathrm{His}_{6}-$ domain II by phenyl-agarose chromatography indicated that the PPIase activity coeluted with the $\mathrm{His}_{6}$-domain II protein (Fig. 2B). To illustrate the determination of a low PPIase activity we present the titration of the PPIase activity of the domain II of SurA (Fig. 2C). Fourth, the specificity of domain for various Suc-Ala-Xaa-Pro-Phep-NA substrates is very similar to that of the full-length SurA-His $_{6}$ (Table 1). Most important, both proteins exhibit a high activity with Suc-Ala-Glu-Pro-Phe--p-NA substrate, a characteristic not observed for Parvulin, the cytoplasmic cyclophylin, and more important, for periplasmic cyclophylin RotA. This protein is the most active periplasmic PPIase and would be the most likely to contaminate the periplasmic SurA- $\mathrm{His}_{6}$ fractions. Finally, a similar PPIase activity of $7.8 \times 10^{3} / \mathrm{M}$ per sec was reported recently by Missiakas et al. (1996) for SurA purified by a different protocol.

\section{The surA mutant has a defective outer membrane}

Several phenotypes of the surA mutant cells suggest that, as expected, they had a defective cell envelope: sur $A^{-}$colonies lysed on plates, cytoplasmic $\beta$-galactosidase diffused out of $\operatorname{sur} A^{-}$colonies, and $\operatorname{sur} A^{-}$cells showed increased sensitivity to several agents whose entrance is normally limited by the outer membrane /crystal violet, polymyxin B, SDS-EDTA, phenetyl alcohol, rifampicin, data not shown), as observed also by Lazar and Kolter (1996). In fact, the stationary phase phenotype that originally defined the gene was related to its altered envelope properties. The specific requirement for surA during stationary phase reflects the increased sensitivity of such cells to lysis. When stationary phase cells are in a buffered neutral pH environment, SurA is not required for survival (R. Kolter, pers. comm.).

When profiles of outer membrane proteins from sur $A^{-}$ and wild-type cells were compared, notable differences between outer membrane preparations from the two cell types were observed (Fig. $3 \mathrm{~A}, \mathrm{~B}$ ). OmpF was virtually absent from outer membrane preparations of sur $A^{-}$cells, LamB, the porin for maltodextrins as well as the bacteriophage $\lambda$ receptor, was reduced $\sim 4$ - to 5 -fold and OmpC and OmpA were reduced 2- to 3 -fold compared with similar preparations from wild-type cells. Some minor OMPs appear relatively unaffected by the lack of SurA (indicated by stars on Fig. 3). It is unlikely that the decreases in OMPs result from selective loss of the outer membrane fraction from sur $A^{-}$cells during sample preparation. Similar results were obtained whether sur $A$ outer membranes were processed in parallel with the wild-type membranes and examined by Coomassie staining (Fig. 3A) or processed together with a large excess of wild-type carrier cells and then detected by radioactive labeling (Fig. 3B). In addition, different OMPs were affected to different extents in the surA mutant background. Finally, immunological determinations of the total amount of OmpF (data not shown) or LamB (see below; Fig. 4) in sur $A^{-}$cells gave values for these proteins consistent with those determined from the cell fractionation experiments.

Decreased OMPS in the outer membrane reflect both decreased synthesis and defective assembly

Expression of OMPs is highly regulated, at both the tran- 


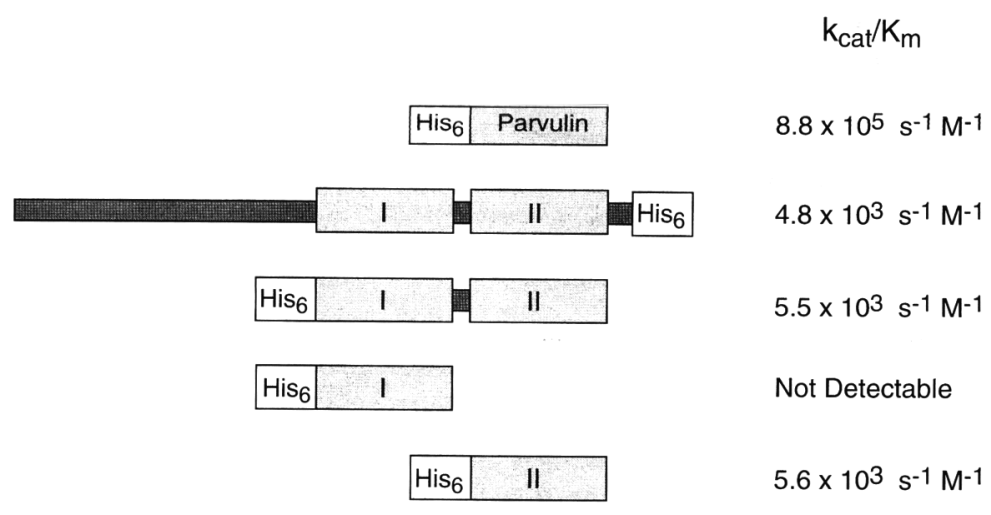

B

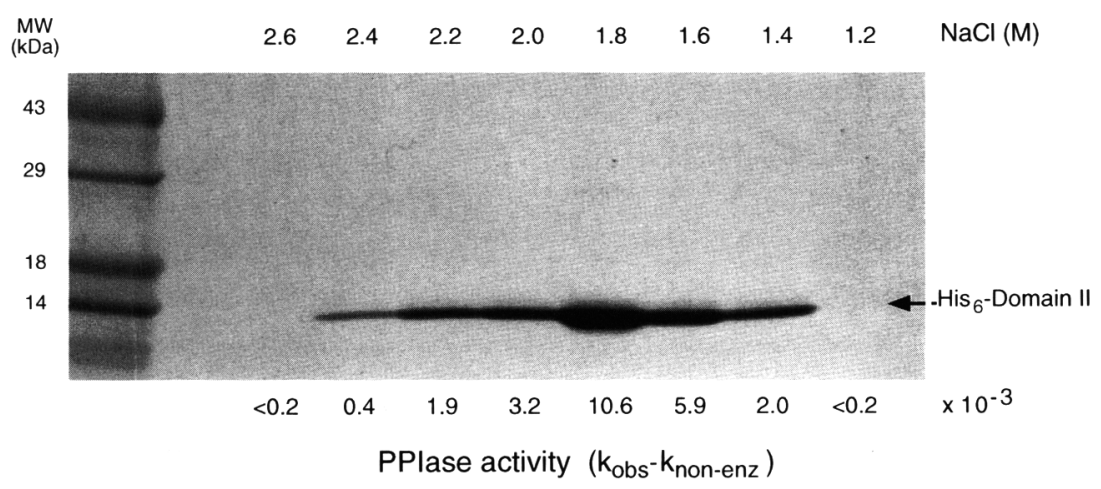

C
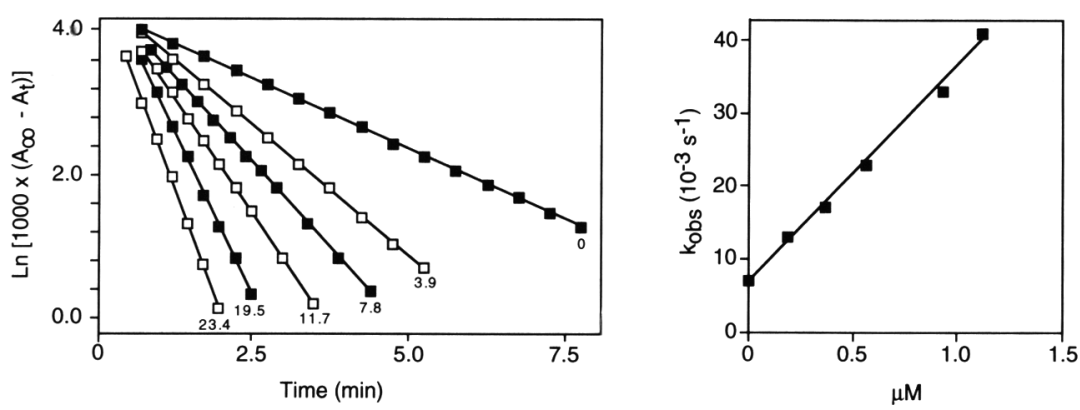

Figure 2. Activity of the Parvulin-like subdomains of SurA. $\mathrm{His}_{6}$-tagged variants of SurA, the two Parvulin-like domains of SurA, and of Parvulin were purified under native conditions by affinity chromatography on $\mathrm{Ni}^{2+}$-agarose and were assayed for PPIase activity with Suc-Ala-Xaa-Pro-Phe-p-NA as described in Materials and Methods. (A) Specific activity of $\mathrm{His}_{6}-\mathrm{SurA}$ and its parvulin domains for the Suc-Ala-Ala-Pro-Phe-p-NA substrate. The $k_{\text {cat }} / K_{\mathrm{m}}$ values reported for the different enzymatic SurA fractions were calculated from the plot of $k_{\text {obs }}$ (per sec) vs. protein $(M)$. The addition of $100 \mu \mathrm{g}$ of SurA $\sim \mathrm{His}_{6}$ doubled the rate of cis to trans conversion. Addition of $100 \mu \mathrm{g}$ of the domain I of SurA did not increase the rate of cis to trans conversion. $(B)$ Coelution of the PPIase activity and the carboxy-terminal domain (domain II) of SurA. After $\mathrm{Ni}^{2+}$-agarose chromatography, the protein was further purified by chromatography on phenyl-sepharose as described in Materials and Methods. PPIase activity was measured using the preferred Suc-Ala-LeuPro-Phe-p-NA substrate. The activity migrated with the peak of $\mathrm{His}_{6}$-domain II. $(C)$ PPIase activity at increasing protein concentrations. Numbers in the left panel refer to micrograms of $\mathrm{His}_{6}$-domain II used in a 1.6$\mathrm{ml}$ assay. The substrate used was Suc-AlaLeu-Pro-Phe-p-NA and the $k_{\text {cat }} / K_{\mathrm{m}}$ was $39.1 \times 10^{3} / \mathrm{M}$ per sec. Substrate specificity of $\mathrm{His}_{6}$-domain II with was tested with the $1.8 \mathrm{M}$ $\mathrm{NaCl}$ fraction (Table 1). scriptional and translational levels. Indeed, there is extensive evidence that perturbation of one OMP can influence expression of other OMPs (Beher and Schnaitman 1981; Catron and Schnaitman 1987; Click et al. 1988; Click and Schnaitman 1989|. Thus, decreased incorporation of proteins into the outer membrane of sur $A^{-}$cells could result from altered OMP expression, impaired OMP assembly, or both. To distinguish these possibilities, we relied on the fact that OMPs incorporated into the outer membrane are stable whereas unassembled OMPs are usually degraded. We therefore compared the initial rate of synthesis and subsequent fate of LamB in wild-type and sur $A^{-}$mutant cells (Fig. 4). Using a pulse-chase labeling experiment, we find that LamB is synthe sized at only $50 \%$ of the wild-type rate in $\operatorname{sur} A$ mutant cells (Fig. 4). The amount of LamB in a surA mutant is only $50 \%$ of that in the wild-type cells after a $30 \mathrm{sec}$ chase. Because degradation of nascent chains in a LamB mutant unable to trimerize is relatively slow (halftime of 3-5 min; Misra et al. 1991) these data indicate that sur $A^{-}$cells have about a twofold defect in LamB synthesis. In addition, $\sim 50 \%$ of the LamB monomers are degraded during the subsequent chase period in $\operatorname{sur} A^{-}$ but not wild-type cells, indicating that sur $A^{-}$cells are defective in LamB assembly. Thus, the 4- to 5-fold decrease in LamB level in sur $A^{-}$outer membranes (Fig. 3) results from defects in both synthesis and assembly. Consistent with this finding, R. Kolter and colleagues 


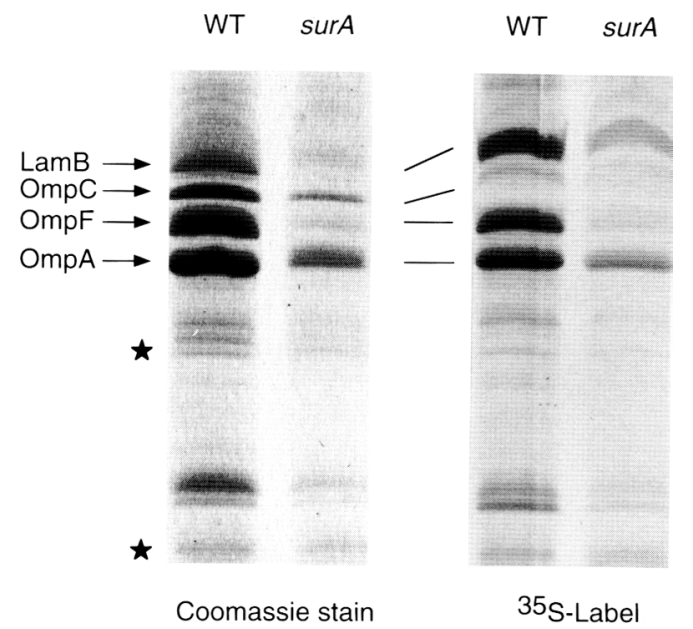

Figure 3. Comparison of OM composition between the surA and wild-type cells. (Left panel) Outer-membrane preparations stained with Coomassie: $10^{10}$ cells grown at $37^{\circ} \mathrm{C}$ in $\mathrm{LB}$ broth containing $0.2 \%$ maltose to $\mathrm{A}_{600}=1$ were mixed with $2 \times 10^{8}$ wild-type cells labeled with ${ }^{35} \mathrm{~S}$-TransMet to be used as a recovery standard. OMs were prepared as described in Materials and Methods and samples containing an equal number of counts were analyzed on 10\% SDS-PAGE gels containing $50 \%$ urea. Known OMP are indicated. The stars indicate OMPs relatively unaffected by the $\operatorname{sur} A$ mutation. (Right panel) OM preparations from cells labeled with ${ }^{35} \mathrm{~S}$-TransMet: wild-type or surA cells exponentially growing in M9 maltose-labeling medium were ${ }^{35} \mathrm{~S}$-labeled $(1-\mathrm{min}$ pulse, $30-\mathrm{min}$ chase). Cells containing the same number of precipitable counts for each sample were mixed with wild-type carrier cells grown in LB maltose and were processed for OM. The same amount of carrier cell protein was analyzed on $10 \%$ SDS-PAGE containing $50 \%$ urea.

have recently reported that sur $A^{-}$cells are defective in converting LamB monomers to trimers (Lazar and Kolter 1996).

In contrast, neither expression nor stability of maltose-binding protein, a periplasmic protein, was altered in sur $A^{-}$cells (Fig. 1C).

\section{SurA affects the formation of a novel intermediate in maturation of OMPs}

The pathway of maturation of outer membrane porins has been studied extensively /Vos-Scheperkeuter and Witholt 1984; De Cock et al. 1990; Misra et al. 1991; Sen and Nikaido 1991a,b; Misra 1993; Van Der Gelder et al. 1994). Concomitant with secretion through the inner membrane, the signal sequence is cleaved, producing a monomer capable of assembly. The active monomers assemble to unstable trimers, which then are converted to stable trimers in a time-dependent process. The two trimeric forms can be distinguished by their differential stability to heat (Vos-Scheperkeuter and Witholt 1984): in $2 \%$ SDS, the unstable trimers are stable below $35^{\circ} \mathrm{C}$ but completely dissociate above $70^{\circ} \mathrm{C}$. In contrast, temperatures above $95^{\circ} \mathrm{C}$ are required to dissociate the stable trimers. Monomers are distinguished from trimers both

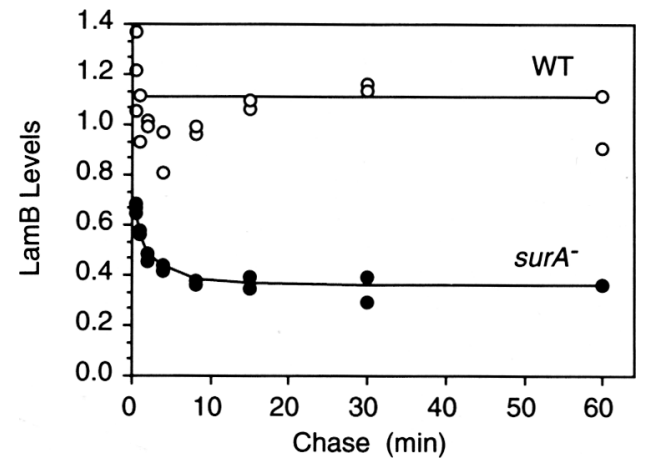

Figure 4. Immunoprecipitation of total LamB. Cells growing exponentially at $37^{\circ} \mathrm{C}$ in $\mathrm{M} 9$ maltose-labeling medium were labeled at $\mathrm{A}_{\mathbf{4} 50}=0.2$ for $30 \mathrm{sec}$ and chased for $0.5,1,2,5,10,15$, 30 , or $60 \mathrm{~min}$. Cellular proteins were precipitated with $5 \%$ TCA and resolubilized in SDS. LamB was immunoprecipitated with anti-LamB monomer antibody and analyzed on $10 \%$ SDSPAGE. Quantitation of total LamB levels was performed with a PhosphorImager. The results from two independent experiments are presented.

by their apparent molecular mass and by their differential sensitivity to monomer- and trimer-specific antibodies. The current model for the pathway of LamB assembly and the techniques used to establish it is presented schematically in Fig. 5A.

To identify where SurA acts in this assembly process, we first documented the process of LamB maturation in wild-type cells (Figs. 5B and 6, top panels) and then compared it with that exhibited by sur $A^{-}$cells (Figs. $5 \mathrm{C}$ and 6 , lower panels). In these experiments we used a pulsechase protocol followed by native immunoprecipitation from cells solubilized in $2 \%$ SDS, using a combination of antimonomer and antitrimer LamB antibodies to precipitate all $\mathrm{LamB}$ species. The immunoprecipitates were then solubilized in $2 \%$ SDS and subjected to differential heating as described above before resolving the various assembly intermediates on SDS-PAGE gels. In the samples heated to $35^{\circ} \mathrm{C}$, only authentic monomer should run as the monomer band, whereas both unstable and stable trimers run as large aggregates that do not enter the resolving portion of the SDS-PAGE gel (Fig. 5B, left). In samples heated to $70^{\circ} \mathrm{C}$, the monomer band should consist of both authentic monomers and dissociated unstable trimers, whereas stable trimers should run at approximately their apparent molecular mass $(90 \mathrm{kD})$ and also as higher molecular mass aggregates (Fig. 5B, right).

The outstanding feature of the maturation process in wild-type cells revealed by these experiments was the presence of an unanticipated species of $\mathrm{LamB}$, designated $\mathrm{f}$-monomer, present in samples heated to $35^{\circ} \mathrm{C}$ (Fig. $5 \mathrm{~B}$, left). In contrast to SDS-unfolded monomeric LamB, which runs at $43 \mathrm{kD}$, this new species runs at $\sim 35 \mathrm{kD}$ and is the major monomeric species initially present in wild-type cells (Fig. 5B, left). f-monomer was shown not to be a LamB degradation product by excising the $\mathrm{f}$-monomer band from the fixed gel, resolubilizing it in 
A

$\begin{array}{lccc} & \text { Monomer } \longrightarrow \text { Metastable Trimer } \longrightarrow \text { Stable Trimer } \\ \begin{array}{c}\text { Precipitating } \\ \text { Antibody }\end{array} & \text { Anti-Monomer } & \text { Anti-Trimer } & \text { Anti-Trimer } \\ \begin{array}{c}\text { Temperature } \\ \text { Stability }\end{array} & \text { Unfolded } & \text { Below } 50^{\circ} \mathrm{C} & \text { Above } 75^{\circ} \mathrm{C}\end{array}$

B

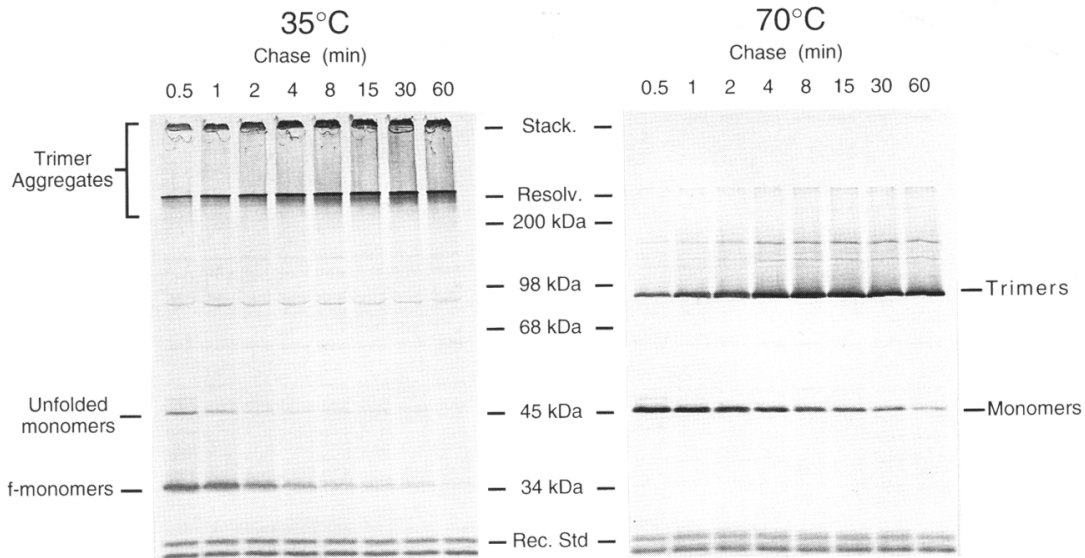

C

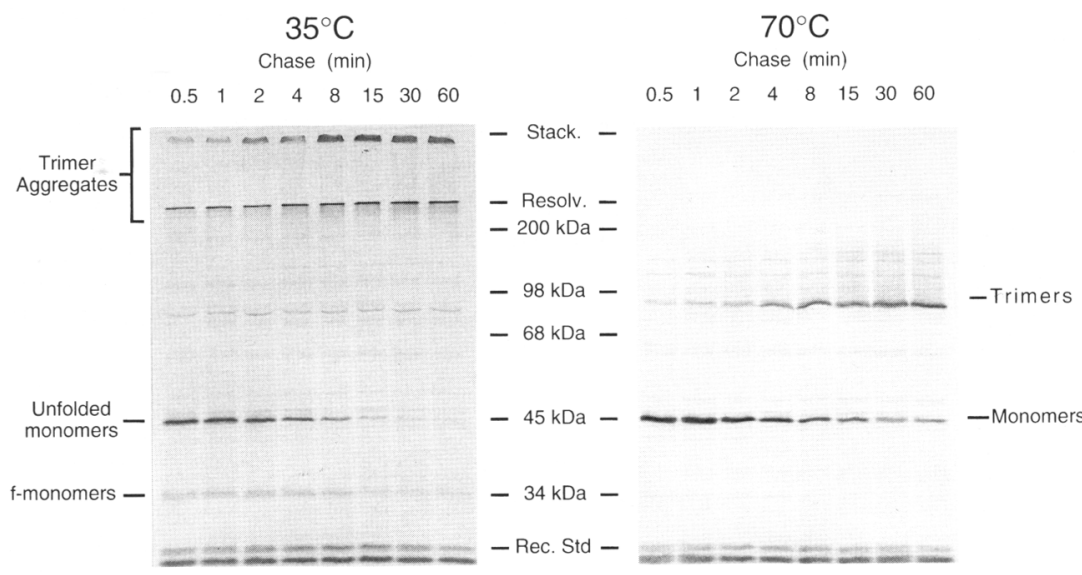

D

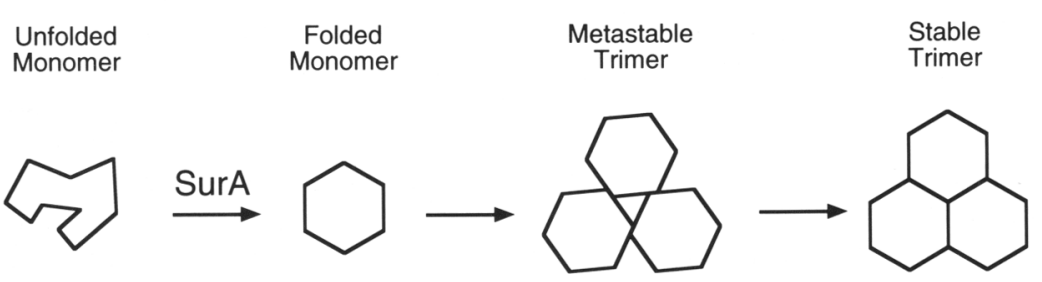

Figure 5. Native immunoprecipitation of LamB. (A) Current model for the assembly pathway of lamB (Vos-Scheperkeuter and Witholt 1984; Misra et al. 1991): The techniques used to distinguish the sequential LamB intermediates are shown below. $(B, C)$ Native immunoprecipitations of LamB from wild-type $(B)$ and sur $A^{-}(C)$ cells: Cells growing exponentially in M9 maltose-labeling medium at $37^{\circ} \mathrm{C}$ were ${ }^{35} \mathrm{~S}$-labeled $(30$-sec pulse), and samples were harvested after increasing length of chase. LamB was immunoprecipitated under native conditions as described in Materials and Methods, resolubilized in sample buffer containing $2 \%$ SDS, and heated to $35^{\circ} \mathrm{C}$ for $5 \mathrm{~min}$. Half of each sample was analyzed by $10 \%$ SDS-PAGE (left panels). The other half of the sample was further heated to $70^{\circ} \mathrm{C}$ for $5 \mathrm{~min}$ prior to analysis by $10 \%$ SDSPAGE (right panels). The $35^{\circ} \mathrm{C}$ gels resolve the monomeric LamB species (entering the resolving gel) from aggregates of trimeric LamB species (not entering the resolving gel). The $70^{\circ} \mathrm{C}$ gels distinguish stable LamB trimers $(90 \mathrm{kD})$ from monomeric and collapsed metastable LamB species $(45 \mathrm{kD})$. In all the gels a contaminant protein migrating above the $\sigma^{\mathrm{E}}$ recovery standard was precipitated with the antitrimer antibodies. Its level is independent of the length of chase. $(D)$ A new model for LamB assembly including the newly identified folded monomer. The step catalyzed by the SurA PPIase is indicated.
$2 \%$ SDS, and reanalyzing it by SDS-PAGE. The f-monomer band then comigrates with unfolded LamB monomer (data not shown). The disappearance of the f-monomer species upon heating to $70^{\circ} \mathrm{C}$ indicates that this spe- cies runs as unfolded monomer under these conditions (Fig. 5B, right). Two features indicate that the f-monomer is likely to be a bona fide intermediate in the process of LamB maturation. First, the rate of disappearance of 

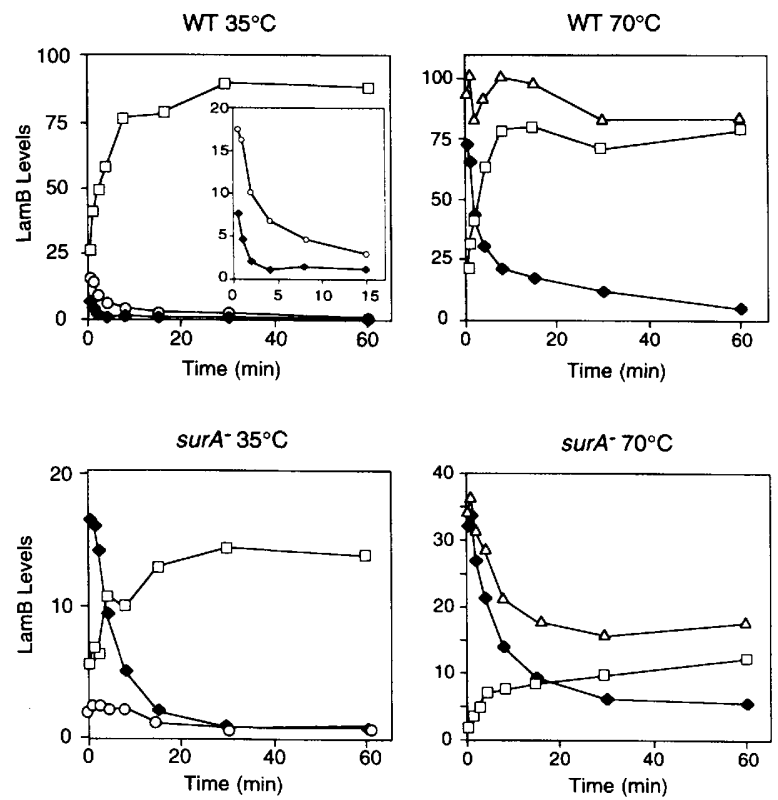

Figure 6. Quantitation of the native immunoprecipitation experiments. Each band in Fig. 5 was quantitated with a PhosphorImager. The numbers are proportional to PhosphorImager counts from the same exposure of the four gels in Fig. 5 and can be directly compared between different experiments. In the gels of samples heated to $35^{\circ} \mathrm{C} \mid(\square)$ trimers; ( ) unfolded monomers; $10 \mid$ folded monomersl, quantitation of the background for the entire smear of LamB trimer aggregates proved unreliable. We quantitated only the intense band at the interface of the resolving and stacking gels. At the earliest timepoints, the significant proportion of LamB trimers present in the smear and not quantitated explains the apparent deficit in the amount of total LamB compared with the $70^{\circ} \mathrm{C}$ experiment $[(\Delta)$ total LamB; $(\square)$ trimers; $(\bullet)$ monomers].

f-monomer is comparable to the rate of appearance of trimer (Fig. 6, top left), suggesting a precursor-product relationship. Second, there is quantitative conversion of the monomer band (which includes f-monomer) to stable trimers in the $70^{\circ} \mathrm{C}$-treated samples (Fig. 5B, right, and Fig. 6, top right).

The surA mutant strain was found to be specifically defective in synthesis of the f-monomer species (Fig. 5C, left). Whereas the f-monomer comprised $\sim 60 \%$ of the total monomeric species in wild-type cells at the beginning of the chase period (Fig. 6, top left), it was only $20 \%$ in sur $A^{-}$cells (Fig. 6, bottom left). The decreased concentration of $f$-monomer in the mutant cells probably resulted from a decrease in the rate of conversion of unfolded monomer to $\mathrm{f}$-monomer. In sur $A^{-}$cells, this process occurred with a half-time of 2 to $3 \mathrm{~min}$, whereas it has a half-time of less than $1 \mathrm{~min}$ in wild-type cells (Fig. 6 , left panels). The simplest model that accounts for these results is that SurA catalyzes the conversion of a precursor species to the $f$-monomer species. This could account for the low level of stable trimers in the surA mutant strain. The slow formation of $\mathrm{f}$-monomer allows time for the degradation and misfolding of intermediate species. In the sur $A$ mutant, the LamB trimers that are assembled are functional because $\operatorname{sur} A^{-}$cells are still sensitive to bacteriophage $\lambda$ (data not shown).

The level of the f-monomer species stayed relatively constant for more than $8 \mathrm{~min}$ in sur $A^{-}$cells. During this time, f-monomers are being formed from the SDS-unfolded species and depleted by incorporation into trimer. Because of this complexity, we are unable to determine whether sur $A^{-}$cells are also defective in converting f-monomer to trimer.

\section{Unfolded monomer accumulates when $\operatorname{Lam} B$ is overexpressed}

The presence of a $\operatorname{sur} A$ mutation induces $\sigma^{\mathrm{E}}$ activity and results in the accumulation of an unfolded monomeric species. $\sigma^{\mathrm{E}}$ activity is also induced by overexpression of OMPs. To test whether OMP overexpression also resulted in accumulation of the unfolded monomer species, we overexpressed LamB from an IPTG-inducible promoter and determined the distribution of LamB assembly intermediates. Upon induction of $\mathrm{LamB}$ with IPTG, $\sigma^{\mathrm{E}}$ activity increased 7.5-fold (data not shown), as reported for the overexpression of other OMPs (Mecsas et al. 1993). Under these conditions, the predominant processed monomer species was the unfolded form, representing $\sim 60 \%$ of the total (Fig. 7). This distribution of monomeric species resembled that observed in the sur $A$ mutant strain (Fig. 5C) rather than that in wild-type cells induced only for chromosomal LamB (Fig. 5B). When LamB was overexpressed, the unfolded monomer pool remained large even after a chase of $30 \mathrm{~min}$, suggesting that it may no longer be in a form that can be converted to f-monomer (Fig. 7). These results suggested that when OMPs are overexpressed, intermediates prior to the $\mathrm{f}$-monomer in the assembly pathway accumulate.

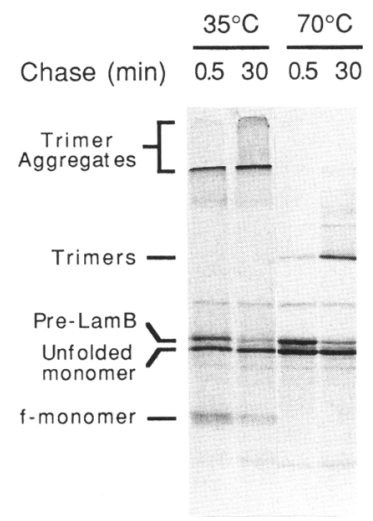

Figure 7. Overexpression of LamB. A culture of strain CAG16037 carrying the LamB overexpressing plasmid pPER99 was grown at $37^{\circ} \mathrm{C}$ in $\mathrm{M} 9$ maltose-labeling medium. When $\mathrm{A}_{450}$ reached 0.2 , LamB overexpression was induced by addition of IPTG. Ten minutes later, the cells were labeled for $30 \mathrm{sec}$ and chased for $30 \mathrm{sec}$ and $30 \mathrm{~min}$. Samples were processed as described in Fig. 5 except that immunoprecipitation was performed from only $10 \%$ of the counts $\left(10^{5} \mathrm{cpm}\right)$. 


\section{Discussion}

This work was initiated to dissect how the cell monitors deleterious conditions in the periplasmic compartment of the cell. To probe this process, we investigated how the overproduction of OMPs activates $\sigma^{\mathrm{E}}$. Although it was known that the inducing signal was generated in the periplasm, the nature of the signal was unknown. To identify periplasmic protein folding agents as well as the inducing signal, we searched for loss of function mutations that simultaneously disrupted OMP assembly and induced $\sigma^{\mathrm{E}}$. Inactivating $\operatorname{sur} A$ conferred the desired phenotype. Our studies indicate that SurA is a periplasmic PPIase, which is involved in the assembly of outer membrane porins. Using the maturation of LamB as a model system, we identified a new intermediate in porin assembly, which we call f-monomer. sur $A^{-}$cells are specifically defective in formation of $\mathrm{f}$-monomer and have aberrantly high levels of the unfolded monomer. Interestingly, overexpression of LamB also leads to high levels of unfolded monomer relative to $\mathrm{f}$-monomer. Both of these conditions activate $\sigma^{\mathrm{E}}$, leading us to suggest that unfolded monomer, or a closely related species, may constitute an inducing signal.

\section{SurA, a representative of a new class of PPIases}

The discovery of Parvulin, a PPIase with no homology to the well established cyclophilin and FKBP families, suggested the existence of a new ubiquitous family of PPIases (Rahfeld et al. 1994; Rudd et al. 1995). So far, $\sim 20$ characterized proteins and translated sequences in organisms ranging from bacteria to man have homology to Parvulin (data not shown). Our finding that SurA has PPlase activity, coupled with the observation that another family member, Pin 1, also has PPIase activity (Lu et al. 1996), strongly suggests that all other family members will likewise possess such an activity. However, that activity may be difficult to find. SurA has only $\sim 1 \%$ of the PPIase activity of Parvulin on peptide substrates in our experiments. This low activity may explain why PTF1, a yeast homolog of Parvulin, has been reported to lack PPIase activity (Hani et al. 1995). Like several FKBP PPIases (Chambraud et al. 1993; Pahl and Keller 1994), SurA has duplicated Parvulin-like domains. Further dissection of SurA will be required to determine whether both domains contribute to SurA activity or specificity. The fact that the Haemophilus influenzae SurA homolog has only one Parvulin domain would suggest that two domains may not be necessary.

Although cyclophilins and FKBP PPIases are ubiquitous, it has been difficult to establish their roles in vivo (Heitman et al. 1991; Breuder et al. 1994; Horne and Young 1995; Kleerebezem et al. 1995). Usually, deletion of the gene has little observable effect, although in a few cases, physiological roles have been identified /Colley et al. 1991; Baker et al. 1994; Franke et al. 1994; Thali et al. 1994; Matouschek et al. 1995; Rassow et al. 1995; Roof and Young 1995). In contrast, all of the Parvulin relatives characterized so far were first identified functionally and in several cases their in vivo function involves the catalysis of some conformational changes in target proteins. Like SurA, the PrsA and PrtM lipoproteins from Grampositive bacteria catalyze the maturation and folding of secreted proteins (Haandrikman et al. 1991; Kontinen and Sarvas 1993). NifM, found in nitrogen-fixing bacteria, is involved in the assembly of the nitrogenase reductase (Howard et al. 1986; Harris et al. 1990). The essential yeast protein PFT1 was identified as a suppressor of mRNA termination (Hani et al. 1995) and human Pin1, which binds to NimA kinase is essential for regulation of mitosis. We suggest that mutations in these genes have phenotypes because these Parvulin relatives are all dedicated proteins whose functions cannot be fulfilled by other PPIases. Indeed the surA mutant has a phenotype even though $E$. coli has at least two other extracytoplasmic PPIases (Liu and Walsh 1990; Hayano et al. 1991; Kleerebezem et al. 1995).

Only the carboxy-terminal half of SurA has clear homology to Parvulin. Likewise, Nif M, PrtM, and PrsA all have substantial domains without homology to Parvulin. These nonhomologous domains may function simply to increase the specific activity of the PPIase by providing specificity for selected substrates. Alternatively, these domains may perform additional folding functions. Certainly, the distinction between chaperones and protein-folding catalysts is becoming blurred, as it is discovered that such proteins may carry out multiple functions. For example, the chaperone DnaJ also promotes the chaperone activity of DnaK and functions as a protein-disulfide isomerase (PDI) (de Crouy-Chanel et al. 1995). Conversely, PDI catalyses refolding of proteins lacking disulfide bonds (Song and Wang 1995). A possible chaperone role independent of proline isomerization has been proposed for cyclophilin (Freskgard et al. 1992), although this interpretation is contested (Kern et al. 1994).

Identification of the f-monomer species suggests a role for SurA in OMP maturation

Our experiments identified a new species in LamB maturation, termed f-monomer, which runs faster on SDSpolyacrylamide gels than unfolded LamB monomers. Several lines of evidence are consistent with the idea that this species is a bona fide intermediate in LamB assembly rather than an off-pathway reaction. (1) $\mathrm{f}$-monomer is the predominant monomeric species in our wild-type strain at early times after synthesis (Fig. 6, top left) and is quantitatively converted to trimer (Fig. 6, top right). (2) Although in vivo experiments are necessarily imprecise, the kinetics of disappearance of f-monomer follows closely that of the appearance of trimer ( $\sim 50 \%$ conversion in 2 min for each process; Fig. 6, top left). (3) The phenotype of sur $A^{-}$cells (see below) is consistent with the idea that f-monomer is an essential intermediate species in assembly. (4) In vitro studies of the phosphate-regulated $\mathrm{PhoE}$ porin and OmpA provide evidence for a folded monomeric species (De Cock et al. 1990a,b; Klose et al. 1993; Van Der Gelder et al. 1994). It is curious that $\mathrm{f}$-monomer has not been previously de- 
scribed in vivo. Two features probably account for this anomaly. First, our protocol uses somewhat lower temperatures than previous procedures, possibly preserving this species more quantitatively $(T$. Silhavy, pers. comm.). In addition, the extent of accumulation of $\mathrm{f}$-monomer is strain-dependent, with little f-monomer present in MC4100, a strain commonly used for OMP expression studies (T. Silhavy, pers. comm.).

What might this intermediate be? Mature LamB is a trimeric porin, whose structure was recently determined (Schirmer et al. 1995). Each monomer in the trimeric structure forms a channel through the outer membrane composed of an 18-stranded antiparallel $\beta$ barrel. One possibility is that the $\mathrm{f}$-monomer species is a LamB monomer that has many (or all) elements of the $\beta$ barrel structure. Such a structure would be expected to be stable under the conditions in which it was detected (heating to $35^{\circ} \mathrm{C}$ in $2 \%$ SDS; denaturing SDS-polyacrylamide gels). Evidence for the idea that $\mathrm{f}$-monomer contains elements of the $\beta$ barrel comes from the observation that it is specifically recognized by the antitrimer antibody (data not shown), indicating that f-monomer shares structural features in common with the trimeric protein.

sur $A^{-}$cells are specifically defective in formation of f-monomer. In such cells, the rate of monomer to trimer conversion is slower than in wild-type cells and is inefficient (cf. Fig. 6 top and bottom left panels). As a result, these strains exhibit only low levels of $f$-monomer and accumulate unfolded monomer to high levels (Fig. 6, bottom left). If, as suggested above, $\mathrm{f}$-monomer is a partially or completely folded $\beta$ barrel, then the SurA protein must participate in formation of this structure. Mature LamB contains eight prolines, of which six are located at ends of $\beta$ strands strategically placed to initiate a turn. Folding of the $\beta$ barrel may require the rapid isomerization of these prolines to bring together successive $\beta$ strands. Isomerization of a single critical proline residue might also nucleate this process. Either of these processes could be facilitated by the SurA PPIase. The fact that the rate of conversion of unfolded monomer to $\mathrm{f}$-monomer in the absence of SurA (2-3 min) is comparable to the time required for the nonenzymatic isomerization of prolyl residues (Schmid 1993; Schmid et al. 1993) is consistent with the involvement of the SurA PPIase in this process. Alternatively, or in addition, SurA may function as a chaperone to facilitate formation of this species. Although our work is limited to the effects of SurA on LamB assembly, is not unreasonable to suggest that SurA is likely to be involved in the formation of folded monomeric intermediates for other if not all OM porins.

The function of the amino-terminal region of SurA is not known. It is tempting to speculate that this region of SurA may play additional roles in the maturation process. Studies on Ts assembly-defective LamB monomers indicate that assembly competent monomers are associated with the OM (Misra et al. 1991). In the folded monomer, the surfaces involved in trimerization as well as those involved in integration into the OM are presumably exposed. Although SurA is associated with folded monomers, it may target them to the OM by interacting either with lipopolysaccharide or other protein components of the OM.

\section{The role of SurA in intercompartmental} communication

The high induction of $\sigma^{\mathrm{E}}$ in the absence of SurA suggests that an intermediate in $O M$ porin assembly prior to $\mathrm{f}$-monomer constitutes the inducing signal. Our experiments indicate that overproduction of OMPs also results in the accumulation of unfolded monomer relative to the f-monomer form, suggesting that accumulation of species prior to folded monomer may constitute a general inducing signal for $\sigma^{\mathrm{E}}$. However, unfolded monomer may be a marker rather than the signal per se. Examination of the species present in wild-type cells immediately following a chase (Fig. 5B) shows a smear of species migrating between authentic unfolded monomer and f-monomer, possibly representing folding intermediates between the unfolded monomer and the f-monomer. In addition, the band of "unfolded monomer" itself may consist of multiple SDS-sensitive species. Unfolded monomer, as well as these partially folded species, could constitute an inducing signal. If SurA is present in limiting amounts, titration by $\mathrm{OM}$ porin overproduction would then produce a signal to induce $\sigma^{\mathrm{E}}$. It is also possible that other, unidentified protein-folding catalysts or chaperones that work upstream of SurA constitute a sensor to gauge the rate of assembly of OM porins.

In addition to the direct effect of SurA on the maturation of OMP intermediates, the absence of SurA affects OMP expression. Half of the decrease in LamB levels in the $\operatorname{sur} A^{-}$mutant resulted from a decrease of expression (Fig. 4). In addition, the absence of SurA has a dramatic effect on OmpF expression. Using operon and protein OmpF-lacZ fusions (Hall and Silhavy 1981), we observed that in $\operatorname{sur} A^{-}$cells, both transcription and translation decreased, resulting in an overall 20 -fold reduction in OmpF expression (data not shown). It has been reported previously that cells lower the expression of some major OMPs in response to overexpression of other OMPs (Diedrich and Fralick 1982; Click et al. 1988; Click and Schnaitman 1989) or a block in maturation (Beher and Schnaitman 1981; Catron and Schnaitman 1987). Lack of SurA may repress OMP expression through this same regulatory loop. The mechanism of this regulation is currently unknown.

\section{Materials and methods}

Insertion mutagenesis and identification of surA

A reporter strain for $\sigma^{\mathrm{E}}$ activity, strain CAG16037 [MC106] $\lambda($ rpoHP3-lacZ) (Mecsas et al. 1993) was transformed with plasmid pJD12, which carries a defective Tn10dCam and the transposase in cis under the control of the Tac promoter, and pMS421 carrying $\mathrm{Iacl}^{\mathrm{Q}}$ (Heath et al. 1992). Synthesis of the transposase, and thus transposition, was induced by addition of IPTG. Ten thousand cells were spread on MacConckey lactose Cam plates and incubated at $30^{\circ} \mathrm{C}$. Because CAG16037 contains the $\sigma^{E_{-}}$ 
dependent promoter rpoHP3 driving the expression of $l a c Z$, cells with elevated $\sigma^{\mathrm{E}}$ activity should appear deep red whereas wild-type cells are light pink. Dark red colonies were purified and inoculated in LB broth containing $10 \mu \mathrm{g} / \mathrm{ml} \mathrm{Cam}$ to grow P1vir. Strain CAG16037 was transduced with each lysate made from an insertion strain to confirm that the increase of $\sigma^{\mathrm{E}}$ activity was caused by the insertion. The insertion was moved to a clean background by P1 transduction into strain CAG 16037 and selected for $\mathrm{Cam}^{\mathrm{R}}$. One stable isolate, strain PER191, was further studied.

Using the Hfr and Tnlo insertion strains of the mapping kit of Singer et al. (1989), the TnlodCam insertion was mapped between 1 and 2 min of the E. coli genetic map $17 \%$ and $50 \%$ cotransduction with a Tn10 markers at min 0.75 and 2, respectively). To further locate the insertion, the gene disrupted by the Tnl0dCam was cloned from a Pst 1 genomic digest of strain PER191. Sequencing showed that the transposon was inserted 165 bases downstream of the ATG initiating codon of the gene surA (Tormo et al. 1990) at bp 54,197 of the E. coli map (Yura et al. 1992).

\section{$\sigma^{E}$ activity assay}

The activity of $\sigma^{\mathrm{E}}$ in the surA::Tn10dCam strain was assayed both by measuring the expression of the $\beta$-galactosidase in cells growing exponentially in M9 glucose medium (Miller 1972) from the reporter fusion rpoHP3-lacZ where P3 is the $\sigma^{\mathrm{E}}$-dependent promoter of $r p o H$ (Erickson and Gross 1989) as well as by $\mathrm{Sl}$ nuclease protection experiments of the transcripts originating at the $\mathrm{P} 2$ promoter of $r p o E$, a $\sigma^{\mathrm{E}}$-dependent gene (Rouvière et al. 1995).

Overexpression and purification of SurA-His ${ }_{6}$ and parvulin-like domains of SurA

A DNA fragment carrying the surA gene and engineered to contain the NcoI and BglII restriction sites (underlined) was amplified by PCR using oligonucleotides $5^{\prime}$-CACGTAAT CCATGGTGCGGTTAATCGAAAT-3' and 5'-GGGTTTTAA AGATCTGTTGCTCAGGATTTTAAC- $3^{\prime}$ and cloned in the NcoI and $B g I I I$ sites of expression vector pQE60 (Qiagen) yielding plasmid pPER93. This plasmid was used to overexpress and secrete a carboxy-terminal SurA-His 6 fusion protein in the periplasm. SurA-His ${ }_{6}$ was purified from the periplasmic fraction of IPTG-induced cells with $\mathrm{Ni}^{2+}$ agarose as described (Qiagen literature, Qiagen Inc., Chatsworth, CA). To attain the greatest purification, the $\mathrm{Ni}^{2+}$ agarose resin (typically $1-2 \mathrm{ml}$ ) was washed two or three times batchwise with $50 \mathrm{ml}$ each of 10 $\mathrm{mm}$ Tris, $5 \%$ glycerol, $300 \mathrm{~mm} \mathrm{NaCl}$ containing 5,10 , and 15 $\mathrm{mm}$ imidazole. The resin was then poured into a small column and the protein eluted by increasing the imidazole concentration. SurA- $-\mathrm{His}_{6}$ eluted at $80 \mathrm{~mm}$ imidazole.

Fragments of the surA gene corresponding to domains with a strong homology with Parvulin (PpiC) (Rahfeld et al. 1994; Rudd et al. 1995) were amplified by PCR using oligonucleotides 5'-GCACTGAGCTCAACCTGAGCCACATC-3', 5'-GATATTTAAGCTTTCGCCGCGCAGGTC-3', 5'-GTG ACCGAGCTCCATGCTCGCCATATT-3' and 5'-GGTTTTATCAAGCTTACGGGTATCCAGCAG-3' (Fig. 2) and cloned in the SacI and HindIII sites of the N-His ${ }_{6}$ expression vector pQE30 (Qiagen) to yield plasmids pPER94 (Domain I, SurA amino acids 175-278), pPER95 (Domain II, SurA amino acids 286-384), and pPER96 (Domain I+ II, SurA amin oacids 175384). To be used as a control, ppiC was also cloned in pQE30 (plasmid pPER97) using oligonucleotides 5'-CTCAAGGCGAGCTCATGGCAAAAACAGCAG-3' and 5'-CTCCTGGAGAAAAGCTTGCTATTAGTTGCG-3'. Plasmids pPER94,
pPER95, pPER96, and pPER97 were maintained in a strain expressing the $l a I^{Q}$ repressor because overexpression in the cytoplasm of Parvulin and the Parvulin-like domains of SurA is toxic. Cells containing each of these plasmids were induced by IPTG and cytoplasmic extracts were prepared by sonication. The three $\mathrm{His}_{6}$-tagged SurA domains accounted for $\sim 50 \%$ of the total cellular protein, whereas that of $\mathrm{His}_{6}-\mathrm{PpiC} \sim 5 \%$. The native $\mathrm{His}_{6}$ protein fusions were purified from each cytoplasmic extract by affinity chromatography on $\mathrm{Ni}^{2+}$-agarose with extensive washes as described above. The $\mathrm{His}_{6}$-domain II was further purified on a phenyl-agarose column equilibrated in $50 \mathrm{~mm}$ Tris- $\mathrm{HCl}$ at $\mathrm{pH} 7.0$ containing $4 \mathrm{M} \mathrm{NaCl}$. $\mathrm{NaCl}$ was added to the extracts to the concentration of $4 \mathrm{M}$, the fraction loaded onto the resin, and eluted with a decreasing $\mathrm{NaCl}$ gradient. The PPIase activity and the $\mathrm{His}_{6}-$ domain II coeluted at $1.8 \mathrm{M} \mathrm{NaCl}$ (Fig. 2B).

\section{PPIase assay}

PPIase activity was assayed spectrophotometrically by measuring at $390 \mathrm{~nm}$ the appearance of nitroanilide resulting from the cleavage of the trans isomer of Suc-Ala-Xaa-Pro-Phe-p-NA by chymotrypsin. This substrate was dissolved in $460 \mathrm{~mm} \mathrm{LiCl}$ in trifluoroethanol as described (Heitman et al. 1993) to increase the concentration of the cis isomer. The assay was performed at $4^{\circ} \mathrm{C}$ with a spectrophotometer placed in a cold room. The PPIase fraction to be tested $(20-100 \mu \mathrm{l})$ was added immediately prior to the beginning of the reaction to a cuvette placed in the light path of the spectrophotometer and containing $1 \mathrm{ml}$ of $50 \mathrm{~mm}$ HEPES, $100 \mathrm{~mm} \mathrm{NaCl}$ buffer, and $800 \mu \mathrm{g}$ of chymotrypsin. Half a milliliter of the contents of the cuvette was drawn with a pipette, mixed rapidly with $10-20 \mu \mathrm{l}$ of $5 \mathrm{~mm}$ Suc-Ala-XaaPro-Phe-p-NA substrate aliquoted in a microfuge tube, pipetted back into the cuvette, and mixed rapidly. The increase of absorbance was plotted by a chart recorder until complete cleavage of the substrate. The rate constant of the reaction $\left(k_{\mathrm{obs}}\right)$, the slope of the plot of $\operatorname{Ln}\left[\mathrm{A}_{390}(\infty)-\mathrm{A}_{390}(t)\right]$ versus $t(\mathrm{sec})$, was measured for various concentrations of enzyme and $k_{\text {cat }} / K_{\mathrm{m}}$ was calculated from the plot of $k_{\mathrm{obs}}$ (per sec) versus PPIase concentration $(M)$. The plot of $\operatorname{Ln}\left[\mathrm{A}_{390}(\infty)-\mathrm{A}_{390}(t)\right]$ versus $t(\mathrm{sec})$ was linear over several minutes, indicating that the proteins were not significantly degraded by the chymotrypsin used in the assay. In the absence of substrate, the rate of the nonenzymatic isomerization for the different substrates was between $4 \times 10^{-3} / \mathrm{sec}$ and $10 \times 10^{-3} / \mathrm{sec}$. The assay was very reproducible and within a set of experiments, an increase of $20 \%$ over the uncatalyzed rate was considered significant. Although the PPIase activity of SurA was low, the catalyzed rates were between 2- and 8-fold greater than the uncatalyzed rate.

\section{Labeling of cells with ${ }^{35}$ S/methionine and cysteine}

Cells to be radioactively labeled were grown at $37^{\circ} \mathrm{C}$ in $\mathrm{M} 9$ medium (Miller 1972) containing vitamins and all amino acids except met and cys. The carbon source was either maltose $(0.2 \%)$ and glycerol $(0.4 \%)$ (M9 maltose-labeling medium) or glucose $(0.2 \%)$ (M9 glucose-labeling medium). When $\mathrm{A}_{450 \mathrm{~nm}}$ reached 0.2 , cells were labeled with a pulse of ${ }^{35} \mathrm{~S}$ Trans-Met $(20$ $\mu \mathrm{Ci} / \mathrm{ml}$ of culture) (Amersham, Arlington Heights, IL) and chased with cold met + cys for various times as described.

\section{Preparation of outer membranes}

Outer membranes were prepared from $10^{10}$ cells pelleted in an Eppendorf tube and resuspended in $500 \mu \mathrm{l}$ of $100 \mathrm{mM}$ Tris- $\mathrm{HCl}$ at $\mathrm{pH} 8.0$ and $10 \mathrm{~mm}$ EDTA. Cell walls were digested with lysozyme $(100 \mu \mathrm{g} / \mathrm{ml})$ on ice for $10 \mathrm{~min}$. The spheroplasts sus- 
pension was adjusted to $10 \mathrm{mM} \mathrm{MgCl}_{2}$ and $50 \mathrm{mg} / \mathrm{ml}$ DNAse I and was lysed by three freeze-thaw cycles. The lysate was centrifuged for $15 \mathrm{~min}$ at $15,000 \mathrm{~g}$. The pellet /crude membrane fraction) was washed with $500 \mu \mathrm{l}$ of $20 \mathrm{~mm} \mathrm{NaPO}_{4}$ at $\mathrm{pH} 7.0$. The cytoplasmic membrane was solubilized with $100 \mu \mathrm{l}$ of $0.5 \%$ sarcosyl in $20 \mathrm{~mm} \mathrm{NaPO}_{4}$ at $\mathrm{pH} 7.0$ at room temperature for $30 \mathrm{~min}$. The insoluble outer membranes were pelleted by centrifugation at $15,000 \mathrm{~g}$ for $15 \mathrm{~min}$, washed once with sarcosyl solution, centrifuged again, and resuspended in $100 \mu \mathrm{l}$ SDS sample buffer $(2 \%$ SDS, $5 \% \beta$-mercaptoethanol, $50 \mathrm{~mm}$ Tris- $\mathrm{HCl}$ at pH $6.8,10 \%$ glyceroll. OMPs were analyzed on a $12 \%$ polyacrylamide SDS gel in the presence of $50 \%$ (wt./vol.) urea to resolve OmpC and OmpF.

To compare OMPs in the wild-type and the surA mutant, cultures were grown in $\mathrm{LB}$ broth at $37^{\circ} \mathrm{C}$ and $10^{10}$ cells were harvested in late exponential phase. In a surA mutant, the yield of OM was lower. To account for possible losses of recovery, the same OM preparation was performed with $2 \times 10^{8}{ }^{35} \mathrm{~S}$-labeled wild-type cells (1 min pulse, $30 \mathrm{~min}$ chase) used as an internal recovery standard. The labeled cells contributed $2 \%$ of the Coomassie stained proteins seen on the gels (Fig. 3). Alternatively, the analysis was performed from $2 \times 10^{\times}$wild-type or sur $A^{-}$cells grown in maltose labeling medium, labeled as above ( 1 min pulse, 30 min chase) and mixed with $10^{10}$ cold wild-type carrier cells grown in LB containing maltose $(0.2 \%)$. The OM were prepared as described above from an equal number of TCA precipitable counts. Labeled OMPs were analyzed on a $12 \%$ SDS gel and the relative incorporation of ${ }^{35} \mathrm{~S}$-met measured with a PhosphorImager (Molecular Dynamics).

\section{Immunoprecipitation of $\operatorname{Lam} B$}

The total amount of $\mathrm{LamB}$ was quantitated at different times $(0.5,1,2,5,10,15,30$, and $60 \mathrm{~min})$ after synthesis using a pulse-chase protocol. Cells were grown in M9 maltose-labeling medium at $37^{\circ} \mathrm{C}$ and labeled as above (30-sec pulse), chased for increasing amount of time, and transferred in cold TCA $15 \%$ final concentration). Precipitated proteins were resolubilized in $50 \mu \mathrm{l}$ SDS sample buffer ( $2 \%$ SDS, $5 \% \quad \beta$-mercaptocthanol, 50 $\mathrm{mm}$ Tris- $\mathrm{HCl}$ at $\mathrm{pH} 6.8,10 \%$ glycerol) and boiled for $3 \mathrm{~min}$ Triton $\mathrm{X} 100(1 \%)$ in $50 \mathrm{~mm}$ Tris at $\mathrm{pH} 7.5$ was added to decrease the SDS concentration below $0.1 \%$. LamB was immunoprecipitated as described from $2 \times 10^{6} \mathrm{cpm}$ using LamB monomerspecific antiserum (Misra et al. 1991).

The amount of the various LamB assembly intermediates was quantitated using native immunoprecipitations as described. Cells labeled as above were transferred in $\mathrm{NaN}_{3}(200 \mathrm{~mm})$ and chloramphenicol $(0.2 \mathrm{mg} / \mathrm{ml})$ and frozen immediately on dry ice. Cells were pelleted by centrifugation $15 \mathrm{~min}$ at $16,000 \mathrm{~g}$, $4^{\circ} \mathrm{Cl}$, resuspended in $50 \mu \mathrm{l}$ of lysozyme $(10 \mathrm{mg} / \mathrm{ml})$ in $50 \mathrm{~mm}$ Tris at $\mathrm{pH} 7.5$ and $1 \mathrm{~mm}$ EDTA, and lysed by two freeze-thaw cycles. SDS and EDTA were added to the final concentration of $2 \%$ and $10 \mathrm{~mm}$, respectively, and the extract was incubated at $25^{\circ} \mathrm{C}$ for $5 \mathrm{~min}$ to solubilize the membranes. Then $1.2 \mathrm{ml}$ of $1 \%$ Triton X100 in $20 \mathrm{~mm}$ Tris at $\mathrm{pH} 7.5$ was added to each sample to lower the SDS concentration below $0.1 \%$ and allow immunoprecipitation. Extracts containing the $\sigma^{\mathrm{E}}$ protein specifically labeled $\left(10^{4} \mathrm{cpm}\right)$ using a $\mathrm{T} 7$ expression system (plasmid pPER76) (Rouvière et al. 1995) were added as an internal control to extracts containing $10^{6}$ precipitable $\mathrm{cpm}$. These cells had been grown in $\mathrm{M} 9$ glucose-labeling medium to repress LamB synthesis and do not contribute LamB in the experiment. LamB species and $\sigma^{\mathrm{E}}$ were precipitated with a mixture of antisera specific for LamB monomers, LamB trimers, and $\sigma^{\mathrm{E}}$ for $2 \mathrm{hr}$ at $0^{\circ} \mathrm{C}$. Antibody/antigen complexes were extracted with Staphylococcus aureus A cells (Sigma Chemical Co., St. Louis, MO) for $1 \mathrm{hr}$ and recovered by centrifugation. Staph A cells were washed three times with $1 \%$ Triton in $20 \mathrm{~mm}$ Tris at $\mathrm{pH} 7.5$ and resuspended in SDS sample buffer. To distinguish the various assembly intermediates of LamB, samples were heated to $35^{\circ} \mathrm{C}$ for 5 min. Half of each sample was analyzed by $10 \%$ SDS-PAGE and the remaining half was further heated to $70^{\circ} \mathrm{C}$ for $5 \mathrm{~min}$ prior to analysis on $10 \%$ SDS-PAGE. The electrophoresis was performed slowly at room temperature at $3 \mathrm{~V} / \mathrm{cm}$ to limit denaturation of the fast migrating LamB monomer ( $\mathrm{f}$-monomer) by heating of the gel (Fig. 5B). The relative level of each LamB intermediates was quantitated with a PhosphorImager. Background was quantitated from an equal surface below the band of interest.

\section{Identification of the "fast" LamB species as a full-length LamB monomer}

The portion of the dried fixed gels containing "fast migrating" Lam $B$ bands (f-monomer) from native immunoprecipitation $\mathrm{ex}$ periments / wild-type extracts, $0.5 \mathrm{~min}, 35^{\circ} \mathrm{C}$-heated sample, Fig. $5 \mathrm{~B}$ ) was excised. The gel slices were rehydrated with $25 \mu$ l SDS sample buffer at room temperature for $16 \mathrm{hr}$ to solubilized the proteins, and were then loaded in the well of a $1.5-\mathrm{mm}$ thick $10 \%$ SDS gel and subjected to electrophoresis. To attest of the identity (comigration) with full-length denatured LamB monomer, the bands of denatured monomer ( $s u r A$ extracts, $0.5 \mathrm{~min}$, $35^{\circ} \mathrm{C}$-heated sample, Fig. $5 \mathrm{Cl}$ were subjected to the same protocol and run side by side.

\section{Overproduction of $\operatorname{LamB}$}

The $\operatorname{lamB}$ gene was amplified by PCR using the oligonuclcotides 5'-AAGAAAAGGAATTCCGGAGGAGATAGAATGATGATTAC-3' and 5'-TAAGACGCGCAAGCTTCGCATCAGGCGTTGGTTG- $3^{\prime}$ and cloned into the expression vector pKK223-3 (Pharmacia Biotech, Piscataway, NI), yielding plasmid pPER99. Strain CAG16037 carrying plasmid pPER99 and a lacl ${ }^{\circ}$ plasmid was grown at $37^{\circ} \mathrm{C}$ in $\mathrm{M} 9$ glucose-labeling medium to repress the chromosomal $\operatorname{lam} B$ copy. When $\mathrm{A}_{450}$ reached 0.2 , LamB overexpression was induced by addition of 1 mM IPTG. Ten minutes later, the cells were labeled (30-sec pulse) and chased for $30 \mathrm{sec}$ and $30 \mathrm{~min}$. Samples were processed as described above except that immunoprecipitation was performed from only $10^{5}$ of precipitable counts.

The amino terminus of the mature SurA was obtained by microsequencing from $100 \mu \mathrm{g}$ of SurA-His ${ }_{6}$.

\section{Acknowledgments}

We thank T. Silhavy for suggesting the native immunoprecipitation expcriments and $\mathrm{H}$. Nikaido for suggesting that the $\mathrm{f}$-monomer might be a $\beta$-barrel monomer. We also thank $\mathrm{C}$. Turc for sequencing the amino terminus of SurA, L. Chi Zen and K. Kopiko for excellent technical assistance to purify and assay ovcrproduced proteins, Christine Cosma and T. Silhavy for providing anti-LamB antisera, J. Heitman for the gift of h-Cyp and y-FKBP12, and John Beckwith for the gift of anti-MBP anti-DegP antiserum. FK506 and Cyclosporin A were gifts from Fujisawa and Sandoz, respectively.

The publication costs of this article were defrayed in part by payment of page charges. This article must therefore be hereby marked "advertisement" in accordance with 18 USC section 1734 solely to indicate this fact.

\section{References}

Baker, E.K., N.J. Colley, and C.S. Zuker. 1994. The cyclophilin homolog NinaA functions as a chaperone, forming a stable 
complex in vivo with its protein target rhodopsin. $E M B O /$. 13: $4886-4895$.

Bardwell, J.C., K. McGovern, and J. Beckwith. 1991. Identification of a protein required for disulfide bond formation in vivo. Cell 67: 581-589.

Beher, M.G. and C.A. Schnaitman. 1981. Regulation of the OmpA outer membrane protein of Escherichia coli. I. Bacteriol. 147: 972-985.

Breuder, T., C.S. Hemenway, N.R. Movva, M.E. Cardenas, and J. Heitman. 1994. Calcineurin is essential in cyclosporin Aand FK506-sensitive yeast strains. Proc. Natl. Acad. Sci. 91: $5372-5376$.

Catron, K.M. and C.A. Schnaitman. 1987. Export of protein in Escherichia coli: A novel mutation in ompC affects expression of other major outer membrane proteins. J. Bacteriol. 169: 4327-4334.

Chambraud, B., N. Rouvière-Fourmy, C. Radanyi, K. Hsiao, D.A. Peattie, D.J. Livingston, and E.E. Baulieu. 1993. Overexpression of p59-HBI (FKBP59), full length and domains, and characterization of PPIase activity. Biochem. Biophys. Res. Commun. 196: 160-166.

Chen, R. and U. Henning. 1996. A periplasmic protein (Skp) of Escherichia coli selectively binds a class of outer membrane proteins. Mol. Microbiol. 19: 1287-1294.

Click, E.M. and C.A. Schnaitman. 1989. Export-defective lamB protein is a target for translation control caused by ompC porin overexpression. 1. Bacteriol. 171: 616-619.

Click, E.M., G.A. McDonald, and C.A. Schnaitman. 1988. Translation control of exported proteins that result from OmpC porin overexpression. J. Bacteriol. 170: 2005-2011.

Colley, N.J., E.K. Baker, M.A. Stamnes, and C.S. Zuker. 1991. The cyclophilin homolog ninaA is required in the secretory pathway. Cell 67: 255-263.

Craig, E.A. 1993. Chaperones: Helpers along the pathways to protein folding. Science 260: 1902-1903.

Craig, E.A., B.D. Gambill, and R.J. Nelson. 1993. Heat shock proteins: Molecular chaperones of protein biogenesis. Microbiol. Rev. 52: 402-414.

De Cock, H., D. Hekstra, and J. Tommassen. 1990a. In vitro trimerization of outer membrane protein PhoE. Biochimie 72: $177-182$.

De Cock, H., R. Hendriks, T. De Vrije, and J. Tommassen. 1990b. Assembly of an in vitro synthesized Escherichia coli outer membrane porin into its stable trimeric configuration. J. Biol. Chem. 265: 4646-4651.

de Crouy-Chanel, A., M. Kohiyama, and G. Richarme. 1995. A novel function of Escherichia coli chaperone DnaJ. Proteindisulfide isomerase. I. Biol. Chem. 270: 22669-22672.

Diedrich, D.L. and J.A. Fralick. 1982. Relationship between the OmpC and LamB proteins of Escherichia coli and its influence on the protein mass of the Outer Membrane. I. Bacteriol. 149: 156-160.

Erikson, J.W. and C.A. Gross. 1989. Identification of the sigma E subunit of Escherichia coli RNA polymerase: A second alternate sigma factor involved in high-temperture gene expression. Genes \& Dev. 3: 1462-1471.

Franke, E.K., H.E. Yuan, and J. Luban. 1994. Specific incorporation of cyclophilin A into HIV-1 virions. Nature 372: 359 362.

Freskgard, P.O., N. Bergenhem, B.H. Jonsson, M. Svensson, and U. Carlsson. 1992. Isomerase and chaperone activity of prolyl isomerase in the folding of carbonic anhydrase. Science 258: 466-468.

Haandrikman, A.J., R. Meesters, H. Laan, W.N. Konings, J. Kok, and G. Venema. 1991. Processing of the lactococcal extracellular serine proteinase. Appl. Environ. Microbiol.
57: 1899-1904.

Hall, M.N. and T.J. Silhavy. 1981. Genetic analysis of the major outer membrane proteins of Escherichia coli. Annu. Rev. Genet. 15: 91-142.

Hani, J., G. Stumpf, and H. Domdey. 1995. PTFl encodes an essential protein in Saccharomyces cerevisiae, which shows strong homology with a new putative family of PPIases. FEBS Lett. 365: 198-202.

Harris, G.S., T.C. White, J.E. Flory, and W.H. Orme-Johnson. 1990. Genes required for formation of the apoMoFe protein of Klebsiella pneumoniae nitrogenase in Escherichia coli. $J$. Biol. Chem. 265: 15909-15919.

Hayano, T., N. Takahashi, S. Kato, N. Maki, and M. Suzuki. 1991. Two distinct forms of peptidylprolyl-cis-trans-isomerase are expressed separately in periplasmic and cytoplasmic compartments of Escherichia coli cells. Biochemistry 30: 3041-3048.

Heath, J.D., J.D. Perkin, B. Sharma, and G.M. Weinstock. 1992. NotI genomic cleavage map of Escherichia coli K-12 strain MG1655. /. Bacteriol. 174: 558-567.

Heitman, J., N.R. Movva, P.C. Heistand, and M.N. Hall. 1991. FK 506-binding protein proline rotamase is a target for the immunosuppressive agent FK 506 in Saccharomyces cerevisiae. Proc. Natl. Acad. Sci. 88: 1948-1952.

Heitman, J., A. Koller, M.E. Cardenas, and M.N. Hall. 1993. Identification of immunosuppressive drug targets in yeast. Methods 5: 176-187.

Horne, S.M. and K.D. Young. 1995. Escherichia coli and other species of the Enterobacteriaceae encode a protein similar to the family of Mip-like FK506-binding proteins. Arch. Microbiol. 163: 357-365.

Howard, K.S., P.A. McLean, F.B. Hansen, P.V. Lemley, K.S. Koblan, and W.H. Orme-Johnson. 1986. Klebsiella pneumoniae nifM gene product is required for stabilization and activation of nitrogenase iron protein in Escherichia coli. J. Biol. Chem. 261: 772-778.

Kern, G., D. Kern, F.X. Schmid, and G. Fischer. 1994. Reassessment of the putative chaperone function of prolyl-cis/transisomcrases. FEBS Lett. 348: 145-148.

Kleerebezem, M., M. Heutink, and J. Tommassen. 1995. Characterization of an Escherichia coli rotA mutant, affected in periplasmic peptidyl-prolyl cis/trans isomerase. Mol. Microbiol. 18: 313-320.

Klose, M., A. Storiko, Y.D. Stierhof, I. Hindennach, B. Mutschler, and U. Henning. 1993. Membrane assembly of the outer membrane protein OmpA of Escherichia coli. I. Biol. Chem. 268: 25664-25670.

Kontinen, V.P. and M. Sarvas. 1993. The PrsA lipoprotein is essential for protein secretion in Bacillus subtilis and sets a limit for high-level secretion. Mol. Microbiol. 8: 727-737.

Lazar, S.W. and R. Kolter. 1996. SurA assists the folding of $E$. coli outer membrane proteins. J. Bacteriol. 178: 1770-1773.

Liu, J. and C.T. Walsh. 1990. Peptidyl-prolyl cis-trans-isomerase from Escherichia coli: A periplasmic homolog of cyclophilin that is not inhibited by cyclosporin A. Proc. Natl. Acad. Sci. 87: 4028-4032.

Lu, K.P., S.D. Hanes, and T. Hunter. 1996. A human peptidylprolyl isomerase essential for regulation of mitosis. Nature 380: $544-547$.

McMillan, D.R., M.J. Gething, and J. Sambrook. 1994. The cellular response to unfolded proteins: Intercompartmental signaling. Curr. Opin. Biotechnol. 5: 540-545.

Matouschek, A., S. Rospert, K. Schmid, B.S. Glick, and G. Schatz. 1995. Cyclophilin catalyzes protein folding in yeast mitochondria. Proc. Natl. Acad. Sci. 92: 6319-6323.

Mecsas, J., P.E. Rouvière, J.W. Erikson, T.J. Donohue, and C.A. 
Gross. 1993. The activity of sigma E, an Escherichia coli heat-inducible sigma-factor, is modulated by expression of outer membrane proteins. Genes \& Dev. 7: 2618-2628.

Miller, J.H. 1972. Experiments in molecular genetics. Cold Spring Harbor Laboratory, Cold Spring Harbor, NY.

Misra, R. 1993. OmpF assembly mutants of Escherichia coli $\mathrm{K}-12$ : Isolation, characterization, and suppressor analysis. J.Bacteriol. 175: 5049-5056.

Misra, R., A. Peterson, T. Ferenci, and T.J. Silhavy. 1991. A genetic approach for analyzing the pathway of LamB assembly into the outer membrane of Escherichia coli. I. Biol. Chem. 266: 13592-13597.

Missiakas, D., C. Georgopoulos, and S. Raina. 1994. The Escherichia coli dsbC (xprA) gene encodes a periplasmic protein involved in disulfide bond formation. $E M B O$ /. 13: 20132020.

Missiakas, D., J.-M. Betton, and S. Raina. 1996. New components of protein folding in extracytoplasmic compartments of Escherichia coli SurA, FkpA and Skp/OmpH. Mol. Microbiol. 21: 871-884.

Nikaido, H. 1994. Porins and specific diffusion channels in bacterial outer membranes. J. Biol. Chem. 269: 3905-3908.

Pahl, A. and U. Keller. 1994. Streptomyces chrysomallus FKBP33 is a novel immunophilin consisting of two FK506 binding domains; its gene is transcriptionally coupled to the FKBP. 12 gene. $E M B O /$. 13: 3472-3480.

Rahfeld, J.U., K.P. Rucknagel, B. Schelbert, B. Ludwig, J. Hacker, K. Mann, and G. Fischer. 1994a. Confirmation of the existence of a third family among peptidly-prolyl cis/trans isomerases. Amino acid sequence and recombinant production of parvulin. FEBS Lett. 352: 180-184.

Rahfeld, J.U., A. Schierhorn, K. Mann, and G. Fischer. 1994b. A novel peptidyl-prolyl cis/trans isomerase from Escherichia coli. FEBS Lett. 343: 65-69.

Rassow, J., K. Mohrs, S. Koidl, I.B. Barthelmess, N. Pfanner, and M. Tropschug. 1995. Cyclophilin 20 is involved in mitochondrial protein folding in cooperation with molecular chaperones Hsp70 and Hsp60. Mol. Cell. Biol. 15: 2654 2662.

Roof, W.D. and R. Young. 1995. Phi X174 lysis requires slyD, a host gene which is related to the FKB family of peptidylprolyl cis/trans isomerases. FEMS Microbiol. Rev. 17: 213218.

Rouvière, P.E., A. De Las Penas, J. Mecsas, C.Z. Lu, K.E. Rudd, and C.A. Gross. 1995. rpoE, the gene encoding the second heat-shock sigma factor, sigma $\mathrm{E}$, in Escherichia coli. $E M B O$ I. 14: 1032-1042.

Rudd, K.E., H.J. Sofia, E.V. Koonin, G.R. Plunkett, S. Lazar, and P.E. Rouvière. 1995. A new family of peptidyl-prolyl isomerases. Trends Biochem. Sci. 20: 12-14.

Schirmer, T., T.A. Keller, Y.F. Wang, and J.P. Rosenbusch. 1995. Structural basis for sugar translocation through maltoporin channels at 3.1 A resolution. Science 267: 512-514.

Schmid, F.X. 1993. Prolyl isomerase: Enzymatic catalysis of slow protein-folding reactions. Annu. Rev. Biophys. Biomol. Struct. 22: 123-142.

Schmid, F.X., L.M. Mayr, M. Mücke, and E.R. Schönbrunner. 1993. Prolyl isomerases: Role in protein folding. Adv. Protein Chem. 44: 25-66.

Sen, K. and H. Nikaido. 1991a. Lipopolysaccharide structure required for in vitro trimerization of Escherichia coli OmpF porin. J. Bacteriol. 173: 926-928.

1991b. Trimerization of an in vitro synthesized OmpF porin of Escherichia coli outer membrane. J. Biol. Chem. 266: 11295-11300.

Singer, M., T.A. Baker, G. Schnitzler, S.M. Deischel, M. Goel,
W. Dove, K.J. Jaacks, A.D. Grossman, J.W. Erickson, and C.A. Gross. 1989. A collection of strains containing genetically linked alternating antibiotic resistance elements for genetic mapping of Escherichia coli. Microbiol. Rev. 53: 124.

Song, J.L. and C.C. Wang. 1995. Chaperone-like activity of protein disulfide-isomerase in the refolding of rhodanese. Eur. I. Biochem. 231: 312-316.

Thali, M., A. Bukovsky, E. Kondo, B. Rosenwirth, C.T. Walsh, J. Sodroski, and H.G. Gottlinger. 1994. Functional association of cyclophilin A with HIV-1 virions. Nature 372: 363-365.

Tormo, A., M. Almiron, and R. Kolter. 1990. surA, an Escherichia coli gene essential for survival in stationary phase. $I$. Bacteriol. 172: 4339-4347.

Van Der Gelder, P., H. De Cock, and J. Tommassen. 1994. Detergent-induced folding of the outer-membrane protein PhoE, a pore protein induced by phosphate limitation. Eur. I. Biochem. 226: 783-787.

Vos-Scheperkeuter, G.H. and B. Witholt. 1984. Assembly pathway of newly synthesized LamB protein an outer membrane protein of Escherichia coli K-12. I. Mol. Biol. 175: 511-528.

Wulfing, C. and A. Pluckthun. 1994. Protein folding in the periplasm of Escherichia coli. Mol. Microbiol. 12: 685-692.

Yura, T., H. Mori, H. Nagai, A. Ishihama, N. Fujita, K. Isono, K. Mizobuchi, and A. Nakata. 1992. Systematic sequencing of the Escherichia coli genome: Analysis of the 0-2.4 min region. Nucleic Acids Res. 20: 3305-3308. 


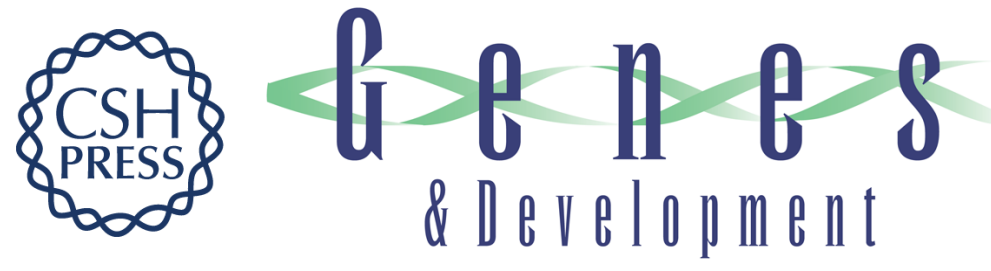

\section{SurA, a periplasmic protein with peptidyl-prolyl isomerase activity, participates in the assembly of outer membrane porins.}

$P$ E Rouvière and C A Gross

Genes Dev. 1996, 10:

Access the most recent version at doi:10.1101/gad.10.24.3170

References This article cites 64 articles, 30 of which can be accessed free at:

http://genesdev.cshlp.org/content/10/24/3170.full.html\#ref-list-1

License

Email Alerting

Service

Receive free email alerts when new articles cite this article - sign up in the box at the top right corner of the article or click here.

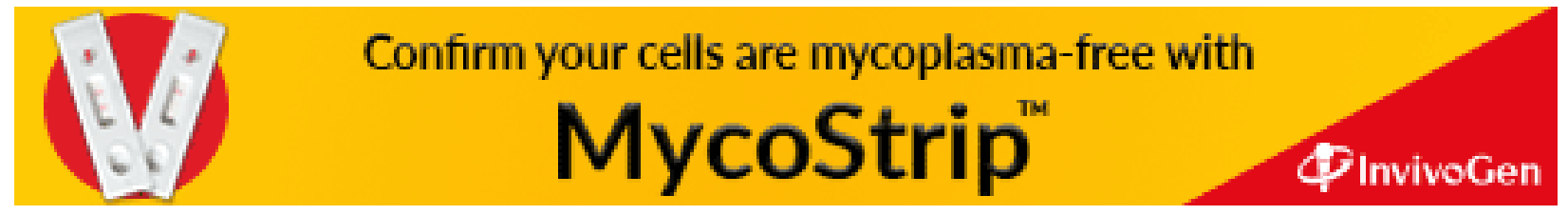

